\title{
Valtioneuvoston periaatepäätös ammatillisen aikuiskoulutuksen kehittämisestä
}

\begin{abstract}
Valtioneuvosto on, asian oltua valmistavasti käsiteltävänä valtioneuvoston raha-asiainvaliokunnassa, opetusministeriön esittelystä päättänyt, että ammatillisen aikuiskoulutuksen kehittämiseksi ryhdytään seuraaviin toimenpiteisiin.
\end{abstract}

\section{Tavoite}

Valtioneuvosto teki 5.3 .1987 periaatepäätöksen ammatillisen aikuiskoulutuksen rahoittamisen suunnitteluperiaatteista. Nyt tehtävällä päätöksellä jatketaan rahjoittamisjärjestelmän ja vastuunjaon selkiyttämistä sekä luodaan edellytyksiä sille, että ammatillista aikuiskoulutusta järjestävät laitokset pystyvät nykyistä joustavammin ja tehokkaammin vastaamaan koulutuksen kysyntään ja siinä tapahtuviin muutoksiin. Erityisesti huomiota kiinnitetään yhteiskunnallisista muutoksista aiheutuviin uudelleenkoulutustarpeisiin. Päätöksen toimeenpanossa otetaan myös huomioon aikuisväestön alueelliset ja sen eri kieliryhmien koulutustarpeet.

Tähän päätökseen sisältyvät toimenpiteet on luokiteltu viiteen ryhmään seuraavasti: omaehtoinen koulutus, henkilöstökoulutus, työllisyyskoulutus, tutkimus- ja kehittämistoiminta sekä muut toimenpiteet.

\section{Omaehtoinen koulutus}

1. Ammatilliseen aikuiskoulutukseen osallistuvien mahdollisuuksia virallisten tutkintojen suorittamiseen kehitetään siten, että tutkintojen osasuorituksina voidaan ottaa huomioon muun muassa aikaisempaa työkokemusta ja aikaisempia opintoja sekä u!komailla suoritettuja opintojaksoja. Opetusministeriö antaa kevätkaudella 1988 asiasta ohjeet alaisilleen keskusvirastoille ja tarvittaessa korkeakouluille.

2. Ammatillista koulutusta järjestävien laitosten omaehtoisen aikuiskoulutuksen tarjontaa lisätään ja monipuolistetaan. Samalla luodaan edellytyksiä niissä toteutettavan henkilöstö- ja työllisyyskoulutuksen tarjonnan laajentamiselle. Tässä tarkoituksessa perustetaan ammatillisiin oppilaitoksiin vuosina 1989-92 ainakin 100 uutta aikuiskoulutus- ja kurssiosastoa.
3. Aikuisten jatko-opintomahdollisuuksia parannetaan siten, että ammatillisen tutkinnon suorittaneille tehdään mahdolliseksi edetä aikaisempien opintojensa pohjalta ylempään tutkintoon ja perehtyä syvällisesti oman alansa suurimpaan kehitykseen. Opetuksen sisältöjä ja järjestelyjä uudistetaan niin, että opiskelu on mahdollista myös työn ohella ja monimuoto-opetuksen mahdollisuuksia hyväksi käyttäen. Tarkoitettua kokeilu- ja kehittämistoimintaa laajennetaan syksystä 1988 alkaen ammatillisissa oppilaitoksissa ja korkeakouluissa.

4. Korkeakoulujen avointa korkeakouluopetusta laajennetaan ja monipuolistetaan valtakunnallisena järjestelmänä siten, että opetista on tarjolla maan kaikissa osissa ja eri koulutusaloilla ja että aikuisilla on todellinen mahdollisuus siirtyä suorittamaan korkeakoulututkintoa 60 opintoviikon suorittamisen jälkeen. Kesäyliopistoja kehitetään muun muassa osana aikuiskoulutusjärjestelmää. Niinikään käytetään hyväksi kansanopistojen sekä kansalais- ja työväenopistojen tarjoamia mahdollisuuksia.

5. Aikuisväestön opiskelumotivaation ja -mahdollisuuksien lisäämiseksi aikuisopintorahakokeilua laajennetaan. Opetusministeriö selvittää yhteistyössä työmarkkinajärjestöjen kanssa millä tavoin työnantajat ja työntekijät osallistuvat aikuisopiskelun rahoitukseen.

\section{Henkilöstökoulutus}

6. Oppisopimuskoulutusta kehitetään myös aikuiskoulutusmuotona. Opetusministeriö asettaa asiaa valmistelemaan toimikunnan kevätkaudella 1988.

7. Ammatillisten kurssikeskusten, ammatillisten ja muiden aikuiskoulutusta antavien oppilaitosten toimintaa kehitetään siten, että yksityiset ja julkiset työnantajat voivat tarpeitaan vastaavasti ostaa niiltä lisäkoulutusta.

8. Korkeakoulujen maksullisena palvelutoimintana järjestämää täydennyskoulutusta laajennetaan. Erityisesti kehitetään nykyistä pidempiä täydennyskoulutusohjelmia kunkin korkeakoulun omalla erityisalalla.

9. Korkeakoulujen yrityspalvelu ${ }^{\dagger}$ oimintaa ja ammatillisten oppilaitosten palvelutoimin- 
taa laajennetaan ottaen huomioon myös aluepoliittiset perusteet. Niihin voidaan sisällyttää myös koulutuspalveluja.

10. Pienyritysten henkilöstökoulutukseen tuleva valtionrahoitus voidaan ottaa valtion tulo- ja menoarviossa sen ministeriön pääluokkaan, jonka toimialaan tarkoitettu yritystoiminta kuuluu.

\section{Työllisyyskoulutus}

11. Työllisyyskoulutuksen tasoa kohotetaan kehittämällä tätä koulutusta muun muassa siten, että siihen osallistuvilla on mahdollisuus edetä samoihin tutkintoihin kuin vastaavassa omaehtoisessa ammatillisessa aikuiskoulutuksessa. Samalla selvitetään edellytykset työllisyyskoulutus-nimikkeen muuttamiseksi nykyistä paremmin ammatillisen aikuiskoulutuksen yleistä luonnetta vastaavaksi. Ammattikasvatushallituksen alaisissa ammatillisissa oppilaitoksissa ja kurssikeskuksissa järjestettävän työllisyyskoulutuksen opetussuunnitelmien perusteiden uudistaminen toteutetaan vuosina 1988-89.

12. Työvoimahallinto tilaa kustannuksellaan työllisyyskoulutuksen ammatillisilta kurssikeskuksilta, ammatillisilta oppilaitoksilta, korkeakouluilta ja muilta koulutuksen järjestäjiltä. Uudistus toteutetaan korkeakouluissa 1989 ja ammattikasvatushallituksen alaisissa laitoksissa 1990.

13. Korkeakoulujen työllisyyskoulutusta kehitetään nykyistä selvemmin kokeilu- ja kehittämistoimintana ja siihen sisällytetään myös tutkimuspalveluja.

14. Ammatilliset kurssikeskukset muutetaan 1990 ammatillisiksi aikuiskoulutuskeskuksiksi, jotka tarjoavat monipuolisia ammatillisia aikuiskoulutuspalveluja. Niiden järjestämä koulutus toteutetaan maksullisena toimintana.

\section{Tutkimus- ja}

\section{kehittämistoiminta}

15. Koulutuksen ja työelämän suhteiden tutkimusta tehostetaan koulutussuunnittelun neuvottelukunnan laatiman tutkimusohjelman pohjalta ottaen erityisesti huomioon aikuiskoulutuksen tarpeet. Lisäksi käynnistetään tutkimus, jonka avulla selvitetään muun muassa rakennemuutoksen kohteena olevissa yrityksissä työskentelevien henkilöiden koulutustausta ja -tarpeet sekä koulutukseen osallistumisen edellytykset.

16. Kehitetään kattava aikuiskoulutuksen tilastointijärjestelmä.
17. Aikuiskoulutukseen suuntautuvaa tutkimusta ja alan tieteellistä koulutusta tehostetaan aikuiskoulutusneuvoston vuonna 1987 valmisteleman aikuiskoulutuksen tutkimuspoliittisen ohjelman pohjalta. Tukea ohjataan nykyistä enemmän aikuiskoulutuksen perusteita ja kehittämistä koskevaan monitieteiseen ja erityisesti kasvatustieteelliseen tutkimukseen. Lisäksi pyritään yhdessä korkeakoulujen kanssa tehostamaan kasvatustieteiden tiedenkuntien ja osastojen ammatilliseen aikuiskoulutukseen, korkeakoulujen järjestämään täydennyskoulutukseen ja avoimeen korkeakouluopetukseen suuntautuvaa tutkimustoimintaa.

18. Aikuiskoulutuksen menetelmiä sekä erityisesti monimuoto-opetuksessa tarvittavia opiskelijakeskeisiä työtapoja ja oppimateriaaleja kehitetään. Etäopetusta tehostetaan.

19. Opetusministeriön ja työvoimaministeriön yhteistyönä kehitetään aikuiskoulutuksen tieto- ja neuvontapalvelu, joka ylläpitää aikuiskoulutuspalvelujenkattavaa tiedostoa ja antaa tarvittaessa henkilökohtaista opinto-ohjausta.

\section{Muut toimenpiteet}

20. Ammatillista aikuiskoulutusta antavien laitosten keskinäistä yhteistoimintaa tehostetaan. Niiden toimintamahdollisuuksia parannetaan siten, että ne voivat nykyistä tehokkaammin käyttää hyväkseen ulkopuolisia asiantuntijoita. Opettajien opetusja työvelvollisuudet pyritään määrittelemään entistä joustavammin. Lisäksi tehostetaan opettajien jatko- ja täydennyskoulutusta.

21. Opetusministeriö asettaa tämän päätöksen toteuttamista ja ammatillisen aikuiskoulutuksen muuta kehittämistä varten seurantaryhmän, johon kutsut? an myös muiden asianomaisten valtionv ranomaisten, kuntien keskusjärjestöjen ja työmarkkinaosapuolten edustajia.

Toimenpiteiden laajuudesta ja voimavarojen määrästä päätetään vuosittain valtion tulo- ja menoarvioesitysten yhteydessä.

Kokonaisvastuu tämän päätöksen toteuttamisesta kuuluu opetusministeriölle ja muun kuin korkeakouluissa annettavan opetuksen osalta ministeriön alaisille keskusvirastoille sekä aluetasolla lääninhallituksille. Opetusministeriö koordinoi ehdotettujen toimenpiteiden toteuttamista myös muiden ministeriöiden hallinnonaloilla.

Helsingissä 24. päivänä maaliskuuta 1988 